\title{
Evaluation of clinical and pathological response factors to neoadjuvant chemotherapy in breast cancer patients
}

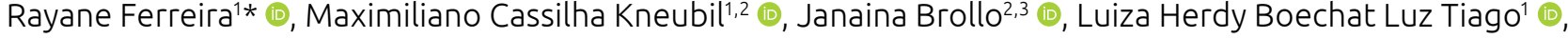

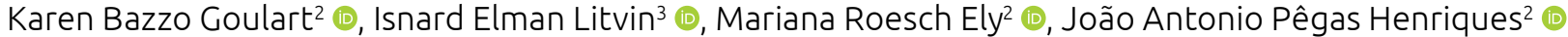

\section{ABSTRACT}

Objectives: To evaluate breast cancer (BC) patients treated with neoadjuvant chemotherapy (NACT) and to analyze clinicopathological features correlating with pathological complete response (PCR) and survival outcomes. Methods: Observational, descriptive, and retrospective study. The medical records of BC patients who underwent NACT were reviewed and analyzed using the Statistical Package for the Social Sciences (SPSS), version 20.0. Results: Of the 176 BC patints who underwent NACT, 62 patients (35.2\%) achieved PCR. The PCR rate was 22\% ( $n=2)$ for luminal A, 15\% $(n=9)$ for luminal B/HER2-negative, $45.5 \%(n=15)$ for luminal $B /$ HER2-positive, 50\% ( $n=14)$ for non-luminal/HER2-positive, and $47.8 \%(n=22)$ for triple-negative $(p=0.01)$. Histological grade, estrogen receptor (ER) expression, progesterone receptor (PR) expression, and HER2 status were significantly associated with PCR $(p=0.022, p=0.01, p=0.01$, and $p=0.02$, respectively). The median follow-up was 35.9 months, the estimated 5 -year disease-free survival (DFS) was $96.7 \%$ in the PCR group and $83.2 \%$ in the non-PCR group ( $p=0.05$ ). The estimated 5 -year overall survival (OS) was $95.5 \%$ in the PCR group and $69.1 \%$ in the non-PCR group ( $p=0.017$ ). Overall, 11 patients (6.25\%) presented with locoregional recurrence (LRR), one (1.6\%) in the PCR group and $10(8.8 \%)$ in the non-PCR group $(p=0.10)$. Conclusion: We observed higher PCR rates in triple-negative and HER2-positive molecular subtypes. DFS and OS were significantly better in patients who achieved PCR, regardless of clinicopathological features. We also observed lower rates of LRR in the population that reached PCR.

KEYWORDS: breast neoplasms; neoadjuvant therapy; molecular biology; residual volume.

\section{INTRODUCTION}

Breast cancer $(\mathrm{BC})$ is a heterogeneous and complex disease ${ }^{1}$. During the last decade, genomic analyzes using microarrays have revolutionized the field of $\mathrm{BC}$ research ${ }^{2}$. Molecular subtypes were identified, outlining different risk factors ${ }^{3,4}$, different prognoses ${ }^{5}$, as well as different natural histories, different survival rates and sensitivity to local and systemic treatments ${ }^{6-9}$.

Neoadjuvant chemotherapy (NACT) is equivalent in overall survival (OS) compared to adjuvant chemotherapy in the treatment of BC. Unlike adjuvant treatment, NACT has traditionally been relegated to patients with locally advanced, initially inoperable BC. However, NACT has played an increasingly important role in the treatment of early-stage disease ${ }^{10}$. NACT has benefits in several clinical strategies, including tumor size reduction and remission of the involvement of the axillary lymph nodes by metastases (downstaging), aiming at a less mutilating surgery, with breast preservation and with resection only of the sentinel lymph nodes in case of negative axillary lymph nodes.

One of the main benefits of NACT is the prognostic information obtained by the pathological evaluation of the tumor bed and axillary lymph nodes after surgery. The complete pathological response is strongly associated with a better prognosis of patients undergoing NACT, as observed in clinical trials NSABP B-18 and B-27 $7^{11,12}$.

Given the arguments presented, we believe that it is extremely important to analyze our population of patients with $\mathrm{BC}$ who underwent NACT and understand the subpopulation of responders and non-responders to conventional treatments, as well as to assess survival outcomes.

${ }^{1}$ General Hospital, Universidade de Caxias do Sul - Caxias do Sul (RS), Brazil.

2Biotechnology Institute, Universidade de Caxias do Sul - Caxias do Sul (RS), Brazil.

${ }^{3}$ School of Medicine, Universidade de Caxias do Sul - Caxias do Sul (RS), Brazil.

*Corresponding author: luuiza_bt@hotmail.com

Conflict of interests: nothing to declare.

Received on: 05/31/2020. Accepted on: 06/11/2020. 


\section{METHODS}

All the medical records of patients who underwent NACT with a diagnosis of breast malignancy, between March 2012 and June 2020 , in the oncology service (UNACON) of the General Hospital (HG) in Caxias do Sul and in the clinic practice were reviewed. The study included all patients who received NACT diagnosis through anatomopathological examination of invasive carcinoma, selecting cases of both non-special invasive breast carcinomas and special breast carcinomas, with histological grades from I to III and with stages from I to IIIC. Data were recorded on forms, as shown in Appendix 1.

The status of estrogen receptor (ER)/progesterone receptor (RP), epidermal growth factor receptor 2 (HER2) protein, and Ki-67 antigen with the following primary antibodies were assessed: monoclonal antibody (MAb) to ER (Dako , clone EP1, prediluted), MAb to RP (Dako, clone PgR, prediluted), MIB-1 MAb to Ki-67 antigen (Dako, clone MIB-1, prediluted) and polyclonal antiserum (Biogen, clone SP3, 1/1,100 dilution) in HER2 protein. Intense and complete membrane staining in at least $10 \%$ of tumor cells was qualified for immunohistochemical expression (IHC) of HER2 3+ and considered to be HER2 positive. For this analysis, HER 2 scores of 0 and $1+$ were considered negative. All HER 2+ tumors were tested for gene amplification by fluorescence in situ hybridization (FISH). The Ki-67 labeling index value was divided into low $(<14 \%)$ and high $(\geq 14 \%)$. Tumors were stratified into subtypes ${ }^{13}$ :

- luminal A: ER positive and/or PR positive, HER2 negative, and low Ki-67 (< 14\%);

- luminal B/HER2 negative: ER positive, PR positive, HER2negative, and Ki-67 high ( $\geq 14 \%$ );

- luminal B/HER2 positive: ER positive, PR positive, HER2 positive, and any Ki-67;

- non-luminal/HER2 positive: ER negative, PR negative, and HER2 positive;

- triple negative: ER negative, PR negative, and HER2 negative.

- Pathologic complete response (PCR) was defined as the absence of invasive carcinoma in the breast and ipsilateral axilla after $\mathrm{NACT}^{14}$.

Regarding the post-NACT pathological evaluation, the pieces were duly evaluated according to well-established international recommendations $s^{15}$. The piece was weighed and measured and the surgical margins were painted with India ink; subsequently, $0.5 \mathrm{~cm}$ slices were cut from anterosuperior to posterior inferior and each slice was labeled as 1, 2, 3, etc. and subdivided into letters A, B, C, etc. (from the upper to the lower axis), setting up a coordinate chart for the assessment of the tumor bed.

Data were entered into Excel and later exported to the Statistical Package for Social Sciences (SPSS), version 20.0, for statistical analysis. Categorical variables were described by frequencies and percentages. Symmetry of quantitative variables was verified using the Kolmogorov-Smirnov test. Quantitative variables were described by mean and standard deviation. Categorical variables were associated using the chi-square test. Quantitative variables were compared between the group with and without PCR using the Student's $t$ test for independent samples. OS and disease-free survival (DFS) were assessed using the Kaplan-Meier curve and compared between groups using the log rank test. Factors associated with PCR with a p-value of less than 0.05 in the bivariate analysis or those considered to be potential confounders were included in a multivariate Cox regression analysis. A significance level of $5 \%$ was considered for the established comparisons.

The OS was analyzed from the date of diagnosis to the date of death or last follow-up (patients who lost follow-up), and the DFS was analyzed from the date of diagnosis to the date of disease progression (locoregional recurrence and/or distant recurrence), date of death (patients who did not show disease progression and evolved to death) or date of last follow-up (patients who lost follow-up).

\section{RESULTS}

One hundred and seventy-six patients with $\mathrm{BC}$ were submitted to NACT at the UNACON of the GH and in the private practice from March 2012 to June 2020. All were included in this analysis. Table 1 shows the clinical characteristics of the population.

The patient population in this sample had a median age of 47.3 years (ranging 24 - 77). It was observed that approximately half of the patients $(n=94 ; 53.5 \%)$ were aged between 35 and 49 years. Regarding the body mass index (BMI), it was noticed that the majority ( $\mathrm{n}=116 ; 65.9 \%$ ) had a BMI $\geq 25$. Furthermore, $86.4 \%$ ( $\mathrm{n}=152$ ) had non-special invasive ductal carcinoma as histological subtype and $40.3 \%(n=71)$ of the patients presented histological grade 3 . The most frequent molecular subtypes were luminal B/ HER2 negative $(n=60 ; 34.1 \%)$ and triple negative $(n=46 ; 26,1 \%)$, and most patients were in clinical stage (CS) IIB $(\mathrm{n}=56 ; 31.8 \%)$ and IIIA ( $\mathrm{n}=52 ; 29.5 \%)$. Of these patients, $145(82.4 \%)$ received regimens based on anthracyclines and taxanes in NACT, 13 (7.38\%) received anthracyclines, taxanes, and carboplatin in NACT, and $18(10.22 \%)$ received other regimens. Fifty-eight (32.9\%) patients received trastuzumab concomitantly with taxane in neoadjuvant therapy and only nine $(5.11 \%)$ received pertuzumab concomitantly with taxane and trastuzumab. Only four HER2 positive patients did not receive trastuzumab in neoadjuvant therapy due to delayed delivery of the medication by the Unified Health System (Sistema Único de Saúde - SUS), but received it during adjuvant treatment.

Regarding the surgical modality, we observed that 84 patients underwent quadrantectomy, 36 adenomastectomy, 10 skin-sparing mastectomy, 39 modified radical mastectomy, and seven did not undergo surgery due to disease progression. According to 
international recommendations, $162(92 \%)$ patients underwent adjuvant radiotherapy after surgery.

After evaluating the surgical specimen, we observed that 62 patients (35.2\%) had PCR and 114 (64.8\%) did not have PCR.

Analyzing all clinical characteristics of patients who entered versus those who did not enter PCR, it was possible to observe a significant association between the molecular subtype and the presence of PCR $(\mathrm{P}=0.001)$. By the adjusted analysis of previously standardized subcategories, it is possible to detect that patients with the triple negative and HER2 positive subtype had a statistically significant higher frequency of PCR, and that the luminal B/HER2 negative subtype had a significantly lower percentage of PCR $(p=0.01)$ (Table 2).

Table 1. Characteristics of the population.

\begin{tabular}{|c|c|c|c|}
\hline $\begin{array}{l}\text { Clinical } \\
\text { characteristics }\end{array}$ & Categories & $\begin{array}{l}\text { Number of } \\
\text { patients }\end{array}$ & $\%$ \\
\hline Total & & 176 & 100 \\
\hline \multirow{4}{*}{ Age (years) } & $<35$ & 15 & 8.5 \\
\hline & $35-49$ & 94 & 53.5 \\
\hline & $50-64$ & 59 & 33.5 \\
\hline & $\geq 65$ & 8 & 4.5 \\
\hline \multirow{3}{*}{ BMI } & $<18.5$ & 3 & 1.7 \\
\hline & $18.5-24.9$ & 57 & 32.4 \\
\hline & $\geq 25$ & 116 & 65.9 \\
\hline \multirow{3}{*}{$\begin{array}{l}\text { Histological } \\
\text { Subtype }\end{array}$} & Lobular & 3 & 1.7 \\
\hline & Ductal & 152 & 86.4 \\
\hline & Medullary & 14 & 8 \\
\hline \multirow{5}{*}{$\begin{array}{l}\text { Histological } \\
\text { Grade }\end{array}$} & Others & 7 & 3.9 \\
\hline & 1 & 12 & 6.8 \\
\hline & II & 57 & 32.4 \\
\hline & III & 71 & 40.3 \\
\hline & Not rated & 36 & 20.4 \\
\hline \multirow{5}{*}{$\begin{array}{l}\text { Molecular } \\
\text { Subtype }\end{array}$} & Luminal A & 9 & 5.1 \\
\hline & $\begin{array}{c}\text { Luminal B/HER2 } \\
\text { negative }\end{array}$ & 60 & 34.1 \\
\hline & $\begin{array}{c}\text { Luminal B/HER2 } \\
\text { positive }\end{array}$ & 33 & 18.8 \\
\hline & $\begin{array}{l}\text { HER2 positive/ } \\
\text { non luminal }\end{array}$ & 28 & 15.9 \\
\hline & Triple negative & 46 & 26.1 \\
\hline \multirow{5}{*}{ Clinical Stage } & $\begin{array}{l}1 \\
I I A\end{array}$ & $\begin{array}{c}4 \\
34 \\
\end{array}$ & $\begin{array}{r}2.3 \\
19.3 \\
\end{array}$ \\
\hline & IIB & 56 & 31.8 \\
\hline & IIIA & 52 & 29.5 \\
\hline & IIIB & 24 & 13.6 \\
\hline & IIIC & 6 & 3.4 \\
\hline
\end{tabular}

BMI: body mass index.
Pathological characteristics such as histological grade, ER expression, RP expression, and HER2 status are associated with PCR with statistical significance, with $p=0.022, p=0.01, p=0.01$, and $p=0.02$, respectively. The other clinicopathological characteristics analyzed, such as age, clinical stage, and Ki-67, did not show a significant correlation with PCR, with $p=0.92, p=0.248$, and $p=0.749$, respectively, which demonstrates that they did not influence the outcome of PCR of this sample (Table 3).

Multivariate analysis by Cox regression showed that patients who presented PCR had better OS regardless of clinical characteristics related to the molecular subtype, ER, PR, and Ki67 (hazard ratio $-\mathrm{HR}=0.15$; 95\% CI $0.04-0.54$ ) (Appendix 2).

The median follow-up was 35.9 months. The five-year DFS for the total sample was $88.8 \%$, for the group with PCR it was $96.7 \%$ and, for the group without PCR, it was $83.2 \%$, with a difference in the limit of statistical significance between groups $(\mathrm{p}=0.05)$ (Figure 1).

The estimated five-year overall survival was $77.8 \%$. When patients were categorized into two groups, with and without CPR, it was possible to observe a significant difference in the estimate of overall survival at five years, with $95.5 \%$ in the group with PCR and $69.1 \%$ in that without PCR ( $\mathrm{p}=0.017$ ) (Figure 2).

Among the 176 patients in the total sample, 11 evolved with locoregional recurrence (LRR) (6.25\%); one LRR in the group with PCR (1.6\%) and 10 LRR were in the group without PCR $(8.8 \%)(p=0.10)$.

\section{DISCUSSION}

Among the 176 patients with BC who underwent NACT in our study, the PCR rate was 35.2\%. Currently, one of the main benefits of NACT is the prognostic information obtained by the pathological evaluation of the tumor bed and axillary lymph nodes after surgery. The PCR is strongly associated with a better prognosis of patients undergoing NACT, as observed in the NSABP B-18 and B-27 clinical trials ${ }^{11,16}$.

In our study, we observed a significant association between the molecular subtype and the presence of PCR $(p=0.001)$, with

Table 2. Association between molecular subtype and PCR.

\begin{tabular}{l|c|c|c} 
Molecular Subtype & $\begin{array}{c}\text { No. of } \\
\text { patients }\end{array}$ & $\begin{array}{c}\text { No. of patients } \\
\text { who reached } \\
\text { PCR (\%) }\end{array}$ & p-value \\
\hline $\begin{array}{l}\text { Luminal A } \\
\text { Luminal B/HER2 } \\
\text { negative }\end{array}$ & & & $\mathrm{p}=$ wsS \\
\hline $\begin{array}{l}\text { Luminal B/HER2 } \\
\text { positive }\end{array}$ & & $\mathrm{p}=0.01$ \\
\hline $\begin{array}{l}\text { HER2 positive non } \\
\text { luminal }\end{array}$ & & & $\mathrm{p}=0.01$ \\
\hline Triple negative & & & $\mathrm{p}=0.01$ \\
\hline
\end{tabular}

wss: without statistical significance. 
PCR rates ranging from 22 to $50 \%$ according to the molecular subtype. This finding is consistent with the literature, in which PCR rates are higher in patients with HER2 positive $B C$ and triple negative $\mathrm{BC}(\mathrm{TN})$ when compared to patients with HER2 negative/hormone receptor positive $\mathrm{BC}^{14,17}$.

In line with data from the world literature, we demonstrated that patients who achieved PCR had significantly higher survival rates compared to those with residual disease. In our study, the five-year DFS for the group with PCR was $96.7 \%$ versus $83.2 \%$ for the group without PCR $(\mathrm{p}=0.05)$. The estimated five-year OS for the group with PCR was $95.5 \%$ versus $69.1 \%$ for the group without PCR $(p=0.017)$. Furthermore, among the patients in our total sample, 11 evolved with LRR (6.25\%); one LRR in the group with PCR (1.6\%) and 10 LRR were in the group without PCR (8.8\%). In the NSABP B-18 study, patients who had post-NACT PCR had longer DFS and greater $\mathrm{OS}(\mathrm{HR}=0.47, \mathrm{p}=0.0001 \text { and } \mathrm{HR}=0.32, \mathrm{p}=0.0001 \text {, respectively })^{18}$.
A therapy based on the assessment of prognostic and predictive factors enables the application of different therapeutic modalities used in cancer treatment with the intensity and effectiveness that are adequate and individualized for each specific patient ${ }^{19}$. In our study, pathological characteristics such as histological grade, ER expression, PR expression, and HER2 status are associated with PCR with statistical significance, with $\mathrm{p}=0.022, \mathrm{p}=0.01, \mathrm{p}=0.01$, and $\mathrm{p}=0.02$, respectively. The other clinicopathological characteristics analyzed, such as age, clinical stage, and Ki-67, did not show a significant correlation with PCR, with $p=0.92, p=0.248$, and $p=0.749$, respectively, demonstrating that they did not influence the outcome of PCR in this sample.

The population in our study consisted mostly of young patients; $53.5 \%$ of them were aged between 35 and 49 years and had tumors in more advanced stages, and $61.3 \%$ had clinical stage

Table 3. Clinicopathological characteristics according to complete pathological responde (PCR).

\begin{tabular}{|c|c|c|c|c|c|}
\hline \multirow{2}{*}{\multicolumn{2}{|c|}{ Characteristics }} & \multirow{2}{*}{ All } & PCR & Without PCR & \multirow{2}{*}{$\mathbf{P}$} \\
\hline & & & $\mathrm{N}(\%)$ & $N(\%)$ & \\
\hline Total & & 176 & 62 & 114 & \\
\hline Age (years), mean \pm SD & & 176 & $46.0 \pm 11.7$ & $48.0 \pm 10.1$ & $p=0.25$ \\
\hline \multirow{4}{*}{ Age (years) } & $<35$ & 15 & $9(14.5)$ & $6(5.3)$ & \multirow{4}{*}{$p=0.92$} \\
\hline & $35-49$ & 94 & $32(51.6)$ & $62(54.4)$ & \\
\hline & $50-64$ & 59 & $18(29.0)$ & $41(36.0)$ & \\
\hline & $\geq 65$ & 8 & $3(4.9)$ & $5(4.3)$ & \\
\hline \multirow{4}{*}{ Histological grade } & 1 & 12 & $2(3.2)$ & $10(8.7)$ & \multirow{4}{*}{$p=0.022$} \\
\hline & II & 57 & $16(25.8)$ & $41(36.0)$ & \\
\hline & III & 71 & $31(50.0)$ & $40(35.1)$ & \\
\hline & not available & 36 & $13(21.0)$ & $23(20.2)$ & \\
\hline \multirow{6}{*}{ Clinical Stage } & I & 4 & $1(1.6)$ & $3(2.6)$ & \multirow{6}{*}{$p=0.249$} \\
\hline & $\| \mathrm{A}$ & 34 & $12(19.4)$ & $22(19.3)$ & \\
\hline & IIB & 56 & $19(30.6)$ & $37(32.5)$ & \\
\hline & IIIA & 52 & $17(27.4)$ & $35(30.7)$ & \\
\hline & IIIB & 24 & $10(16.1)$ & $14(12.3)$ & \\
\hline & IIIC & 6 & $3(4.9)$ & $3(2.6)$ & \\
\hline \multirow{3}{*}{ ER } & $0-9$ & 73 & $36(58.1)$ & $41(36.0)$ & \multirow{3}{*}{$p=0.01$} \\
\hline & $10-49$ & 15 & $6(9.7)$ & $9(7.9)$ & \\
\hline & $\geq 50$ & 84 & $20(32.2)$ & $64(56.1)$ & \\
\hline \multirow{3}{*}{ PR } & $0-9$ & 89 & $43(69.4)$ & $51(44.7)$ & \multirow{3}{*}{$p=0.01$} \\
\hline & $10-49$ & 30 & $8(12.9)$ & $22(19.3)$ & \\
\hline & $\geq 50$ & 52 & $11(17.7)$ & $41(36.0)$ & \\
\hline \multirow{2}{*}{$\mathrm{Ki}-67$} & $<14$ & 11 & $3(4.8)$ & $8(7.0)$ & \multirow{2}{*}{$p=0.749$} \\
\hline & $\geq 14$ & 165 & $59(95.2)$ & $106(93.0)$ & \\
\hline HER2 & $\begin{array}{l}\text { Positivo } \\
\text { Negativo }\end{array}$ & $\begin{array}{c}62 \\
114\end{array}$ & $\begin{array}{l}29(46.8) \\
33(53.2)\end{array}$ & $\begin{array}{l}33(28.9) \\
81(71.1)\end{array}$ & $p=0.02$ \\
\hline
\end{tabular}

ER: estrogen receptor; PR: progesterone receptor. 
IIB (31.8\%) and IIIA (29.5\%). However, clinical stage and age did not have a significant correlation with PCR, which shows that age and tumor size at diagnosis probably do not influence PCR rates in the neoadjuvant setting.

NACT is equivalent in OS compared to adjuvant chemotherapy in the treatment of $\mathrm{BC}$. In contrast to adjuvant treatment, NACT has traditionally been relegated to patients with locally advanced, initially inoperable BC. However, NACT has played an increasingly important role in the treatment of early-stage disease ${ }^{10}$, especially in patients with triple negative BC and HER2 positive, regardless of patient age, with benefits even in elderly patients in good clinical condition.

Another key point in the neoadjuvant scenario is the proper interaction between the pathologist and the surgeon, as the former needs adequate clinical and imaging information, such as tumor size and location, in addition to the presence or absence of a clip in the tumor bed for a careful evaluation of the residual tumor. This was a positive point of our work: the pathologist
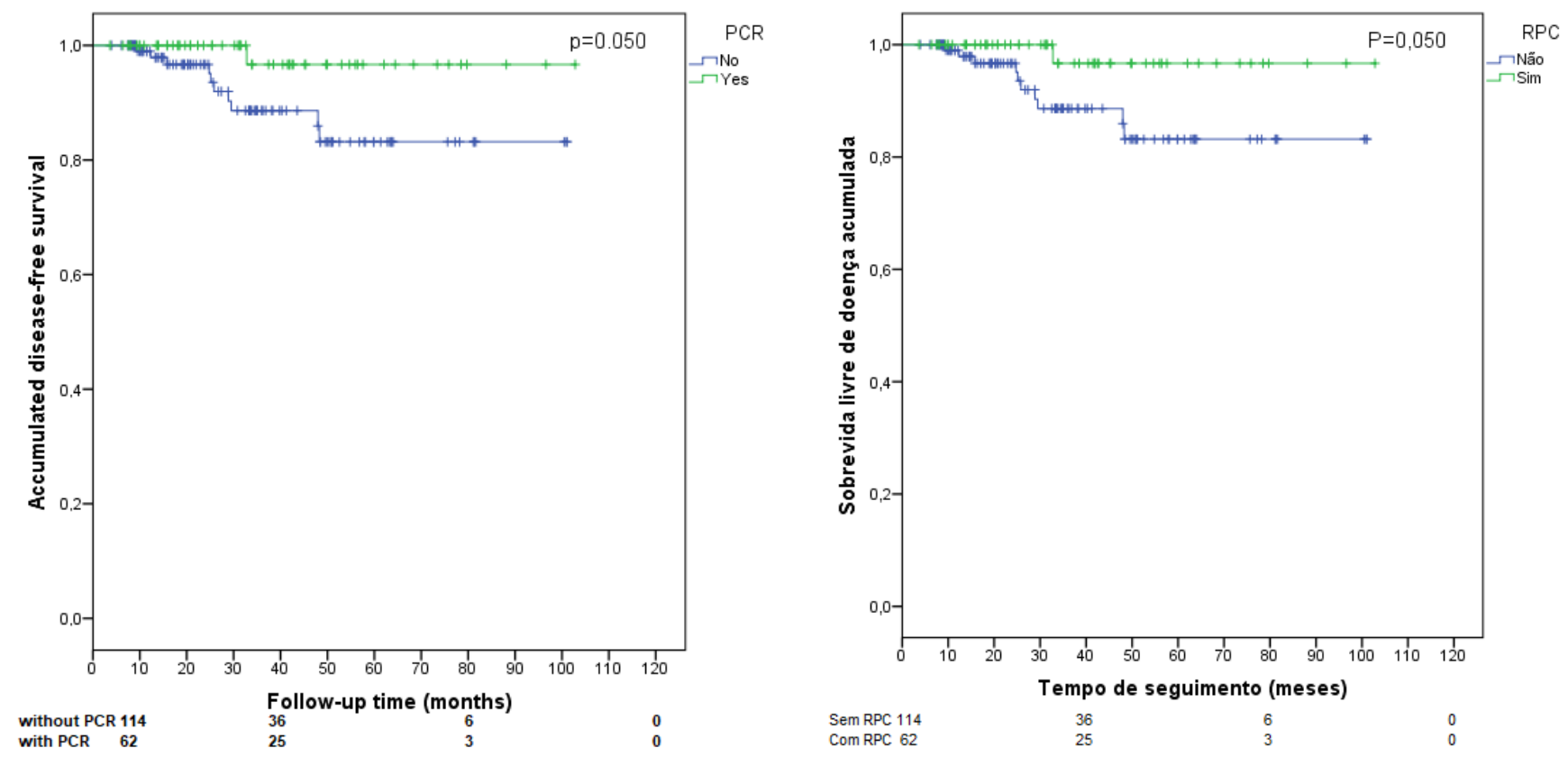

Figure 1. Disease-free survival estimate of patients according to the PCR.
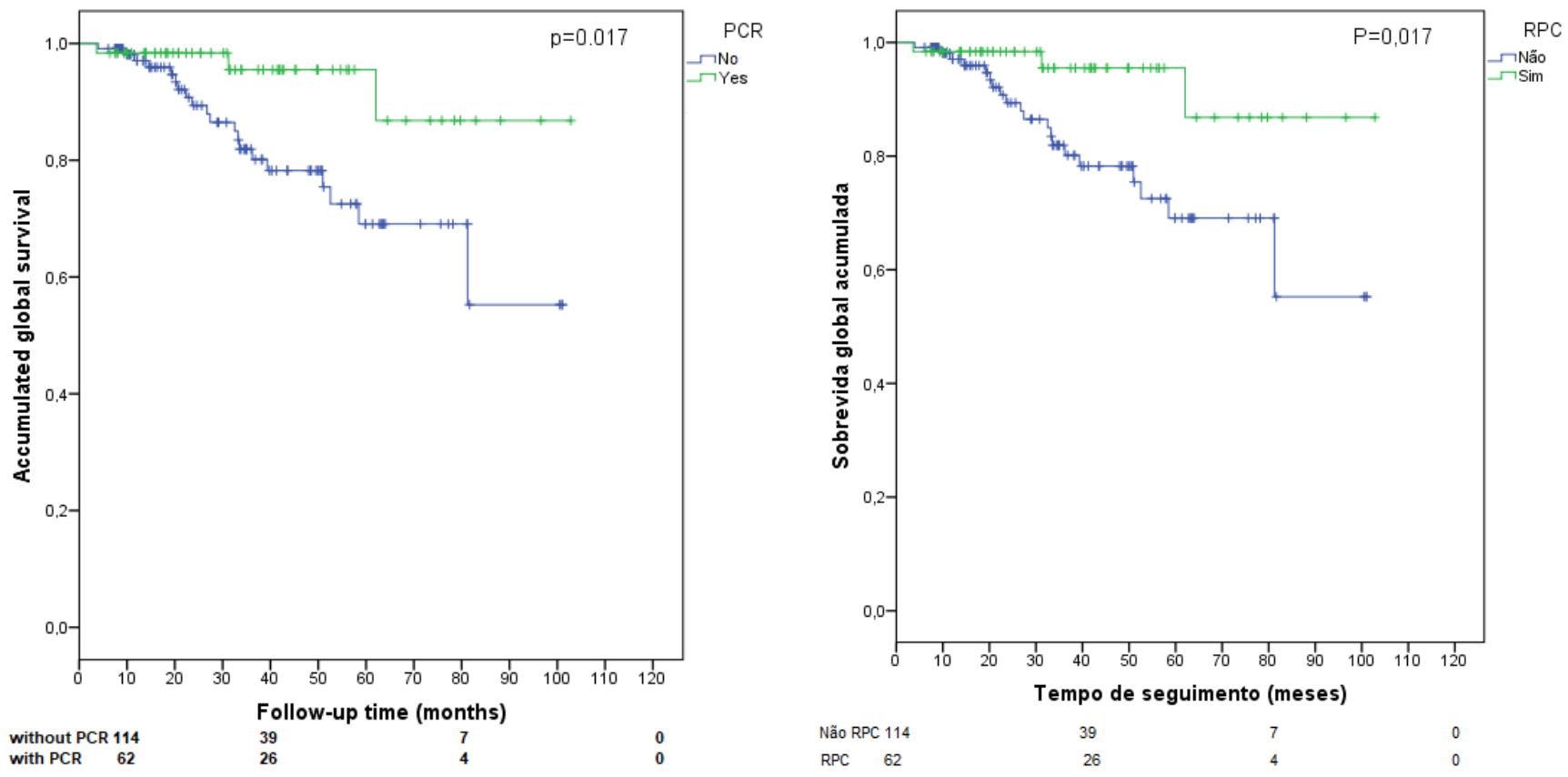

Figure 2. Estimate of overall survival in patients according to PCR. 
presented this necessary and important information before the macroscopic examination of the surgical specimen, directing it to specific serial sections post-NACT according to well-established international recommendations and allowing the anatomopathological result to mirror the extension of post-NACT residual tumor with high accuracy ${ }^{15}$.

Although our study has shown relevant and expected data according to the world literature, we understand that the limitations of this work are related to the small sample, the retrospective nature, and the short follow-up time. In addition, we also observed that a small sample of patients (5.11\%) underwent double HER2 blockade in neoadjuvant therapy.

\section{CONCLUSION}

In our sample of patients with BC undergoing NACT, we observed higher rates of PCR in the triple negative and HER2 positive molecular subtypes. PFS and OS rates were significantly better in patients who achieved PCR, regardless of clinicopathological factors. We also observed lower LRR rates in the population that reached PCR. Thus, we increasingly emphasize the importance of NACT in the approach of the initial BC.

\section{ACKNOWLEDGMENTS}

To the employees of the various intra- and extra-hospital sectors, who contribute to the comprehensive care and treatment of patients with $\mathrm{BC}$.

\section{AUTHORS' CONTRIBUTIONS}

R.F.: Conceptualization, Data curation, Formal analysis, Writing original draft.

Maximiliano Cassilha Kneubil: Conceptualization, Data curation, Formal analysis, Writing - original draft.

J.B.:Project administration, Methodology, Writing - review \& editing. L.H.B.L.T.: Investigation, Writing - review \& editing. K.B.G.: Methodology, Data curation, Formal analysis. I.E.L.: Methodology, Project administration, Validation. M.R.E.: Project administration, Writing - review \& editing. J.A.P.H.: Project administration, Writing — review \& editing.

\section{REFERENCES}

1. Perou CM, Sørlie T, Eisen MB, van de Rijn M, Jeffrey SS, Rees CA, et al. Molecular portraits of human breast tumours. Nature. 2000;406(6797):747-52. https://doi.org/10.1038/35021093

2. Sørlie T, Perou CM, Tibshirani R, Aas T, Geisler S, Johnsen $\mathrm{H}$, et al. Gene expression patterns of breast carcinomas distinguish tumor subclasses with clinical implications. Proc Natl Acad Sci. 2001;98(19):10869-74. https://doi.org/10.1073/ pnas. 191367098

3. Millikan RC, Newman B, Tse CK, Moorman PG, Conway K, Dressler LG, et al. Epidemiology of basal-like breast cancer. Breast Cancer Res Treat. 2008;109(1):123-39. https://doi. org/10.1007/s10549-007-9632-6

4. Phipps AI, Buist DS, Malone KE, Barlow WE, Porter PL, Kerlikowske K, et al. Reproductive history and risk of three breast cancer subtypes defined by three biomarkers. Cancer Causes Control. 2011;22(3):399-405. https://doi.org/10.1007/ s10552-010-9709-0

5. Phipps AI, Chlebowski RT, Prentice R, McTiernan A, Stefanick ML, Wactawaski-Wende J, et al. Body size, physical activity, and risk of triple negative and estrogen receptor-positive breast cancer. Cancer Epidemiol. Biomarkers Prev. 2011;20(3):454-63. https://dx.doi.org/10.1158\%2F1055-9965.EPI-10-0974

6. Wang Y, Klijn JGM, Zhang Y, Sieuwerts AM, Look MP, Yang F, et al. Gene-expression profiles to predict distant metastasis of lymphnode-negative primary breast cancer. Lancet. 2005;365(9460):6719. https://doi.org/10.1016/s0140-6736(05)17947-1
7. Slamon DJ, Clark GM, Wong SG, Levin WJ, Ullrich A, McGuire WL. Human breast cancer: correlation of relapse and survival with amplification of the HER-2/neu oncogene. Science. 1987;235(4785):177-82. https://doi.org/10.1126/ science. 3798106

8. Slamon DJ, Godolphin W, Jones LA, Holt JA, Wong SG, Keith DE, et al. Studies of the HER-2/neu proto-oncogene in human breast and ovarian cancer. Science. 1989;244(4905):707-12. https://doi.org/10.1126/science.2470152

9. Carey LA, Perou CM, Livasy CA, Dressler LG, Cowan D, Conway K, et al. Race, breast cancer subtypes, and survival in the Carolina Breast Cancer Study. JAMA. 2006;295(21):2492502. https://doi.org/10.1001/jama.295.21.2492

10. Haddad TC, Goetz MP. Landscape of neoadjuvant therapy for breast cancer. Ann Surg Oncol. 2015;22(5):1408-15. https:// dx.doi.org/10.1245\%2Fs10434-015-4405-7

11. Fisher B, Brown A, Mamounas E, Wieand S, Robidoux A, Margolese RG, et al. Effect of preoperative chemotherapy on local-regional disease in women with operable breast cancer: findings from National Surgical Adjuvant Breast and Bowel Project B-18. J Clin Oncol. 1997;15(7):2483-93. https://doi. org/10.1200/jco.1997.15.7.2483

12. Mamounas EP. NSABP Protocol B-27. Preoperative doxorubicin plus cyclophosphamide followed by preoperative or postoperative docetaxel. Oncology (Williston Park). 1997;11(6 Suppl. 6):37-40. 
13. Goldhirsch A, Winer EP, Coates AS, Gelber RD, PiccartGebhart M, Thürlimann B, et al. Personalizing the treatment of women with early breast cancer: highlights of the St Gallen International Expert Consensus on the Primary Therapy of Early Breast Cancer 2013. Ann Oncol. 2013;24(9):2206-23. https://doi.org/10.1093/annonc/mdt303

14. Von Minckwitz G, Untch M, Blohmer JU, Costa SD, Eidtmann $\mathrm{H}$, Fasching PA, et al. Definition and impact of pathologic complete response on prognosis after neoadjuvant chemotherapy in various intrinsic breast cancer subtypes. J Clin Oncol. 2012;30(15):1796-804. https://doi.org/10.1200/ jco.2011.38.8595

15. Provenzano E, Bossuyt V, Viale G, Cameron D, Badve S, Denkert C, et al. Standardization of pathologic evaluation and reporting of postneoadjuvant specimens in clinical trials of breast cancer: recommendations from an international working group. Mod Pathol. 2015;28(9):1185-201. https://doi. org/10.1038/modpathol.2015.74
16. Bear HD, Anderson S, Smith RE, Geyer CE Jr., Mamounas EP, Fisher B, etal.Sequential preoperative or postoperative docetaxel added to preoperative doxorubicin plus cyclophosphamide for operable breast cancer: National Surgical Adjuvant Breast and Bowel Project Protocol B-27. J Clin Oncol. 2006;24(13):2019-27. https://doi.org/10.1200/jco.2005.04.1665

17. Houssami N, Macaskill P, von Minckwitz G, Marinovich ML, Mamounas E. Meta-analysis of the association of breast cancer subtype and pathologic complete response to neoadjuvant chemotherapy. Eur J Cancer. 2012;48(18):3342-54. https:/doi. org/10.1016/j.ejca.2012.05.023

18. Rastogi P, Anderson SJ, Bear HD, Geyer CE, Kahlenberg MS, Robidoux A, et al. Preoperative chemotherapy: updates of National Surgical Adjuvant Breast and Bowel Project Protocols B-18 and B-27. J Clin Oncol. 2008;26(5):778-85. https://doi. org/10.1200/jco.2007.15.0235

19. Abreu E, Koifman, S. Prognostic factors in woman breast cancer. Rev Bras Cancerol. 2002;48(1):113-31. 


\section{Apêndice 1. Ficha de avaliação.}

Nome:

Data de nascimento:

Prontuário:

Sexo: $\square$ 1. Feminino; 2. Masculino

Idade ao diagnóstico:

Etnia: $\square$ 1. Branca; 2. Negra; 3. Asiática 4. Parda; 5. Outra.

IMC:__-__-_ Peso:____kg Estatura:____ $\mathrm{cm}$

Performance status: $\square$ 0. $0 ; 1.1 ; 2.2 ; 3.3 ; 4.4$

História prévia de tabagismo: $\square$ 0. Não 1.<20 maços/ano 2. > 20maços/ano

Status menopausal: $\square$ 0. Pré-menopausa; 1. Pós-menopausa

Data do diagnóstico:____________ Laboratório:

Tipo histológico: $\square$ 1. Lobular invasor; 2. Ductal invasor; 3. Outros

Grau histológico (Nottingham): $\square$ 1. G1; 2. G2; 3. G3 99. Não disponível

Expressão ER: $\square$ valor:__-___- 0 . Ausente (0\%); 1 . Baixa ( $\geq 1 \%$ e $<10 \%) ; 2$. Positiva ( $\geq 10 \%$ e $<50 \%) ; 3$. Fortemente positiva $(\geq 50 \%)$

Expressão PgR: $\square$ valor:

HER2: $\square$ 0.0+; 1.1+; 2.2+; 3.3+; 99. Não disponível

Se 2+: $\square$ 0. FISH não amplificado; 1. FISH amplificado; 88. Não se aplica 99. Não disponível

Ki67: $\square$ valor:___-_. Baixo (<14\%); 2. Alto; 3. Não disponível

Subtipo Molecular: 1.Luminal A 2.Luminal B 3.Luminal-HER2 Positivo

4. HER2 Puro 5. Triplo Negativo

TNM inicial

T: $\square$ valor:____(cm) 0. T1mi; 1. T1a; 2. T1b; 3. T1c 4. T2; 5. T3; 6. T4a; 7. T4b; 8. T4c; 9. T4d

T: $\square$ Avaliado por: 0. Exame Físico; 1. Ecografia mamária bilateral; 2 Ambos

$\mathrm{N}: \square$ 0.N0; 1. N1; 2. N2a; 3. N2b; 4. N3a; 5. N3b; 6. N3c

$\mathrm{M}: \square$ 0.M0; $1 . \mathrm{M} 1$

Estádio clínico: $\square$ 1. IA; 2. IB; 3. IIA; 4. III; 5. IIIA; 6. IIIB; 7. IIIC; 8. IV

Se 8 (EC IV), sítio metastático: $\square$ 8a. Fígado; 8b. Pulmão, pleura ou derrame pleural; 8c. Osso; 8d. SNC;

8e. Outros

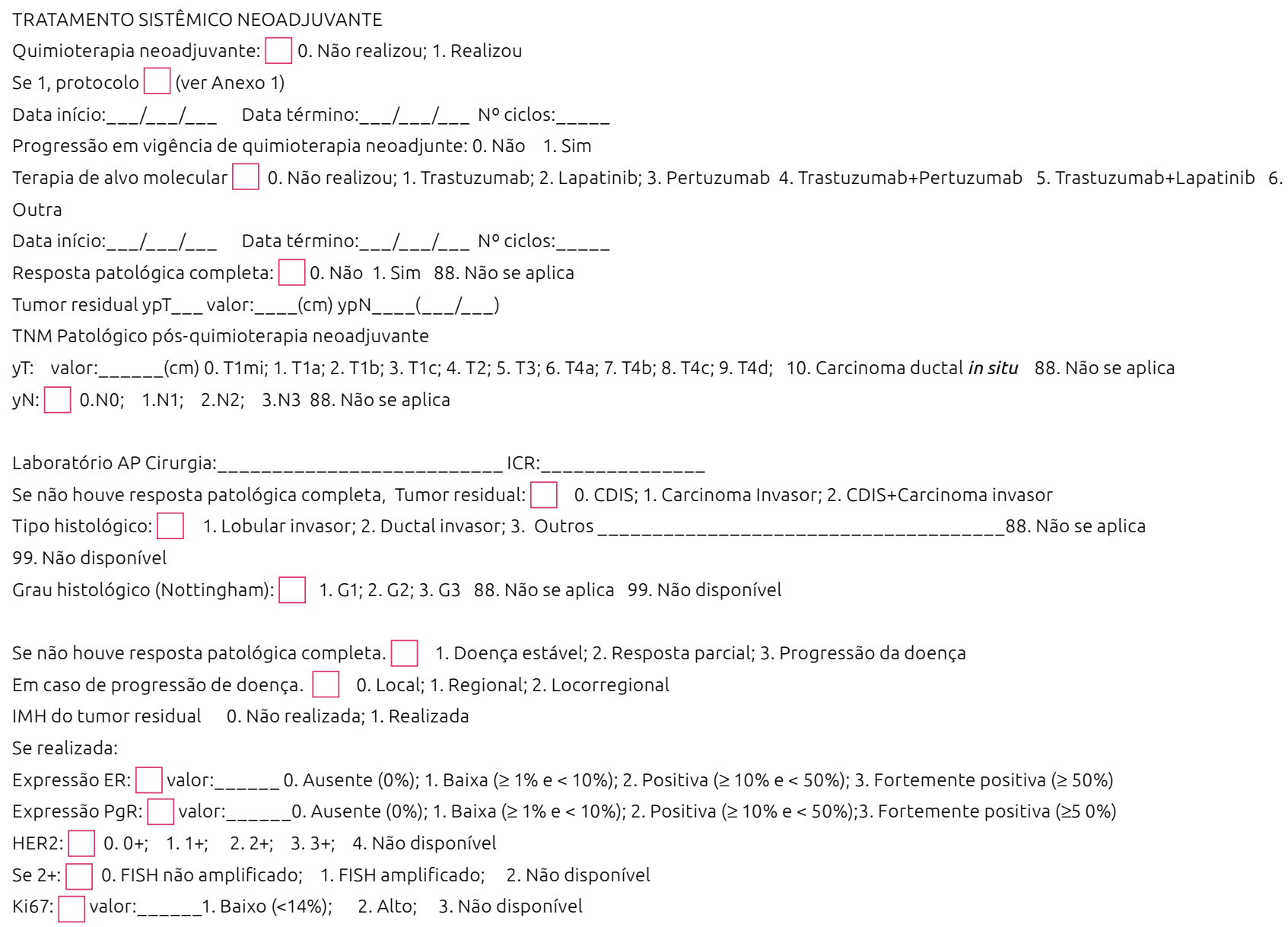


